\title{
Tectogonotoechia rivasi n. sp. A new lower Pragian Celtiberian (Spain) Ancystrorhynchoidea rhynchonellid brachiopod
}

\author{
Jenaro L. GARCÍA-ALCALDE ${ }^{I^{*}}$ \& Zarela HERRERA ${ }^{2}$ \\ ${ }^{1}$ Departamento de Geología, Universidad de Oviedo, c/ Jesús Arias de Velasco, s/n, 33005, Oviedo \\ ${ }^{2}$ Museo de los Mares Paleozoicos, Santa Cruz de Nogueras, c/ La Unión 3, 44497, Teruel \\ * Corresponding author
}

García-Alcalde, J.L. \& Herrera, Z. 2017. Tectogonotoechia rivasi n. sp. A new lower Pragian Celtiberian (Spain) Ancystrorhynchoidea rhynchonellid brachiopod. [Tectogonotoechia rivasi $\mathrm{n}$. sp. Nuevo braquiópodo rinconélido Ancystrorhynchoidea del Praguiense inferior de Celtiberia (España)]. Spanish Journal of Palaeontology, 32 (1), 115-128.

\begin{abstract}
A new lower Pragian Ancystrorhynchoidea rhynchonellid, Tectogonotoechia rivasi $\mathrm{n}$. sp. of the Celtiberian region (Eastern Iberian Chain, EIC, and Eastern Guadarrama, EG) is described and figured. The growth of the new species, from the last neanic stage to the senescent one is specially underlined. T. rivasi $\mathrm{n}$. $\mathrm{sp}$. is characterized as the other species of the genus by the occurrence of a pseudoseptum and a pseudoseptalium in the dorsal interior, with a fine connectivum forming a roofed over structure covering most part of the latter. Exteriorly, the species is a entirely costate, strongly dorsibiconvex, uniplicate form lacking of marginal spines. T. rivasi $\mathrm{n}$. $\mathrm{sp}$. is fairly abundant in the upper part of the Nogueras Formation in the EIC and in the lower third of the Cercadillo Formation in the EG and it is usually accompanied by a varied macrofauna of brachiopods, bryozoans, solitary corals, tabulates, trilobites, ostracods and others. The biocenose of $T$. rivasi $\mathrm{n}$. sp. is characterized by the occurrence of abundant incrusting and boring epizoans colonizing mainly the brachiopods, representing different symbiotic interactions and probably a permanent risk for the epizoans to be buried in an unstable soft substrate.
\end{abstract}

Keywords: Brachiopoda Ancystrorhynchoidea, systematics, ontogeny, palaeoecology, Celtiberia, Spain.

\section{RESUMEN}

Se describe y figura un nuevo rinconélido Ancystrorhynchoidea, Tectogonotoechia rivasi $\mathrm{n}$. $\mathrm{sp}$. y se ilustran los cambios en el crecimiento desde el final de la etapa neánica hasta la senil. El nuevo taxón se caracteriza, como todos los de su género, por la posesión en la valva dorsal de pseudosepto y pseudoseptalio, este último cubierto en su mayor parte por un fino conectivo en forma de techo. Exteriormente, T. rivasi $\mathrm{n}$. sp. es una forma costada, uniplegada y fuertemente dorsibiconvexa que carece de espinas marginales. La nueva especie aparece en toda la región celtibérica (España) en capas del Praguiense inferior (parte superior de la Formación Nogueras, en la Cordillera Ibérica Oriental, CIO y tercio inferior de la Formación Cercadillo, en Guadarrama oriental, GO), junto a una variada macrofauna de braquiópodos, briozoos, corales solitarios, tabulados, trilobites, ostrácodos y otros. La biocenosis de T. rivasi $\mathrm{n}$. sp. se caracteriza por la presencia de numerosos epizoos incrustantes y perforantes, principalmente sobre los braquiópodos, que representan diferentes interacciones simbióticas y denotan, probablemente, el riesgo constante de los epizoos de quedar sepultados en un substrato blando e inestable.

Palabras clave: Brachiopoda Ancystrorhynchoidea, sistemática, ontogenia, paleoecología, Celtiberia, España. 


\section{INTRODUCTION}

The upper part of the Nogueras Formation ( $d 2 c \alpha-d 2 c \beta$, see Carls, 1999; Dojen, 2005), in the Eastern Iberian Chain (EIC) and correlative levels in the Eastern Guadarrama (EG) (Cercadillo Formation, Ce4-Ce5, Bultynck \& Soers, 1971 = beds MS 12-13, Carls, 1999; Carls \& ValenzuelaRíos, 1999) (Figs 1-5) records important lower Pragian bottom-level faunal communities. These associations belong to sub- to inter-tidal environments representing the beginning of a marked rhytmothem detectable along the EIC and EG that could even reach in eastern Armorica (Carls, 1988). They comprise varied and abundant brachiopods, bryozoans, solitary rugose corals, tabulates, trilobites, ostracods and other macro and micro-faunal elements that allow precise correlations along the Celtiberian-Armorican basin. An important fraction of these taxa is waiting to be described (García-Alcalde \& Herrera, 2015). Taking advantage of the largely deserved homage to Professor Pascual Rivas of the Granada University on the occasion of his retirement, a new Celtiberian rhynchonellid species, Tectogonotoechia rivasi $\mathrm{n}$. sp. is proposed, described and figured herein. The new taxon is fairly abundant along the EIC where it is accompanied by a varied brachiopod fauna with, among others, Neopaulinella noguerasensis Schemm-Gregory, 2011, Monsenella inornatoides GarcíaAlcalde, 2013, Torosospirifer gr. rousseaui (Rouault, 1846), Ovetensispirifer cf. ovetensium (Carls, 1986), Davoustia mezquitensis Racheboeuf, 1981, Beethovenia cf. bachi García-Alcalde, 2014, and Trigonirhynchia celtiberica García-Alcalde \& Herrera, 2015. These taxa indicate close relationships between the upper part of $d 2 c \alpha$ and $d 2 c \beta$ submembers of the Nogueras Formation and correlative levels of the Cercadillo Formation with both the upper part of the Lebanza Formation (Member E), in Palencia, and the upper part of the Nieva Formation (Faunal Intervals 5/6 transition) in the coastal Asturian region (Fig. 5).

Tectogonotoechia rivasi $\mathrm{n}$. $\mathrm{sp}$. is a relatively large sized form that belongs to a badly understood, uppermost Silurian-Pragian rhynchonellid group, whose species have usually been placed in Rhynchonella, Camarotoechia, and Ancillotoechia. The critical feature of those species, included the new one, i.e. the occurrence of a dorsal pseudoseptalium and a pseudoseptum (sensu Havlíček \& Storch, 1990), remained unnoticed until recently, resulting in erroneous superfamily, family and genus assignations (García-Alcalde, 1998, 2009; García-Alcalde \& Herrera, 2015). In fact, the occurrence of a pseudoseptalium in Tectogonotoechia García-Alcalde, 1998, sets the genus and their species into the Superfamily Ancystrorhynchoidea Cooper, 1956, Family Iberirhynchiidae García-Alcalde, 2009, Subfamily Iberirhynchiinae García-Alcalde, 2009.

Two Armorican French taxa described by Oehlert (1884), Rhynchonella cypris, d'Orb. and R. subpareti, Oehl. share apparently some external and internal morphological features with $T$. rivasi $\mathrm{n}$. sp. but they are not well known enough (the primary types of $R$. subpareti have been lost, and the original description seems to embrace more than one species; Drot \& L'Hotellier, 1976; Brice, 1980), and poorly illustrated (after drafts, not photographs!) to achieve useful comparisons. Further, $R$. subpareti was included by Brice (1981: 187) in her new genus Stenorhynchia that has a true dorsal septum and septalium.

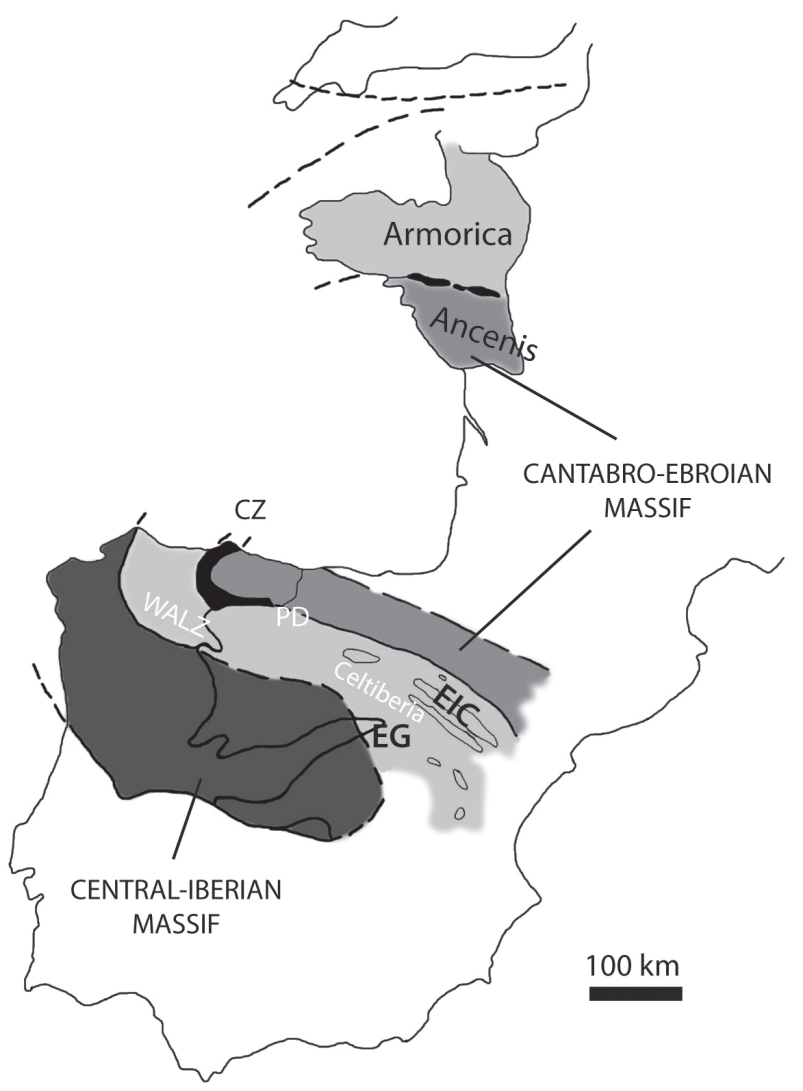

Figure 1. Setting of the Eastern Iberian Chain (EIC) in the paleogeographical Ibero-Armorican context. CZ: Cantabrian Zone; EG: Eastern Guadarrama; PD: Palentian Domain; WALZ: Western Asturo-Leonian Zone (modified from Carls, 1982, 1988).

\section{SYSTEMATICS}

The specimens studied herein are housed in the Collection of the Department of Geology of Oviedo (DPO-DGO).

Morphological terms used in the Tectogonotoechia rivasi $\mathrm{n}$. sp. description are after Williams \& Brunton (1997), Treatise on Invertebrate Paleontology, part H Brachiopoda Revised, volume 1: Introduction, and Savage et al. (2002), Treatise on Invertebrate Paleontology, part H Brachiopoda Revised, volume 4: Rhynchonelliformea (part). 


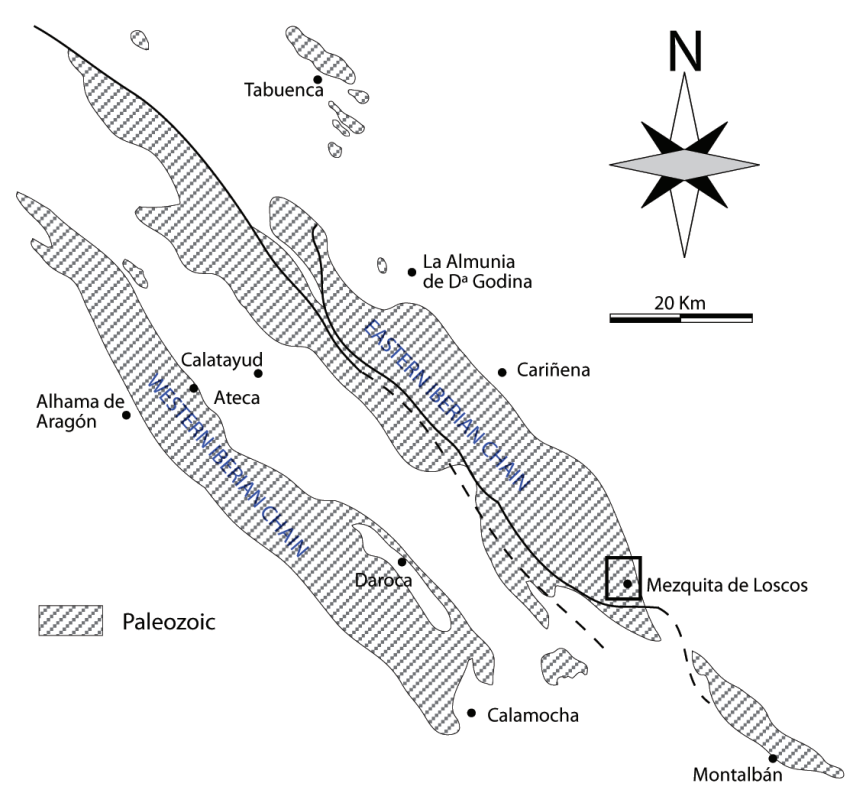

Figure 2. Location of the studied area in the Eastern Iberian branch of the Iberian Chains.

Superfamily Ancistrorhynchoidea Cooper, 1956. Family Iberirhynchiidae García-Alcalde, 2009. Subfamily Iberirhynchiinae García-Alcalde, 2009

\section{Genus Tectogonotoechia García-Alcalde, 1998}

Type species. Tectogonotoechia tectogonia GarcíaAlcalde, 1998, upper part of the lower Lochkovian, Cantabrian Mountains, ? Eastern Guadarrama.

Diagnosis. (slightly emended). Shell small, subtriangular to subpentagonal outline, nearly biconvex to dorsibiconvex, entirely ribbed. Costae angular, simple, strongly indented, with no marginal spines; costae from beaks except those of mid part of ventral sulcus and median dorsal fold that begin a little ahead. Sulcus and fold well-developed, from quarter to mid length; 3-4 costae on sulcus, 4-5 on fold; ventral tongue trapezoidal to triangular, more or less developed, vertical to posterodorsally directed; median longitudinal furrow on dorsal umbo; short and relatively deep; abrupt, lateral margins. Muscle field usually weakly impressed. Dental plates short, supporting teeth simple. Pseudoseptalium, a troughlike structure formed by medially fused crural plates, covered anteriorly by fine plates extending ventrally from crural bases forming a sharp roofed structure (connectivum); pseudoseptalium supported by a median dorsal ridge that rises from the floor of valve upwards as juxtaposed thin sheets of secondary shell (pseudoseptum); pseudoseptum thick and long.

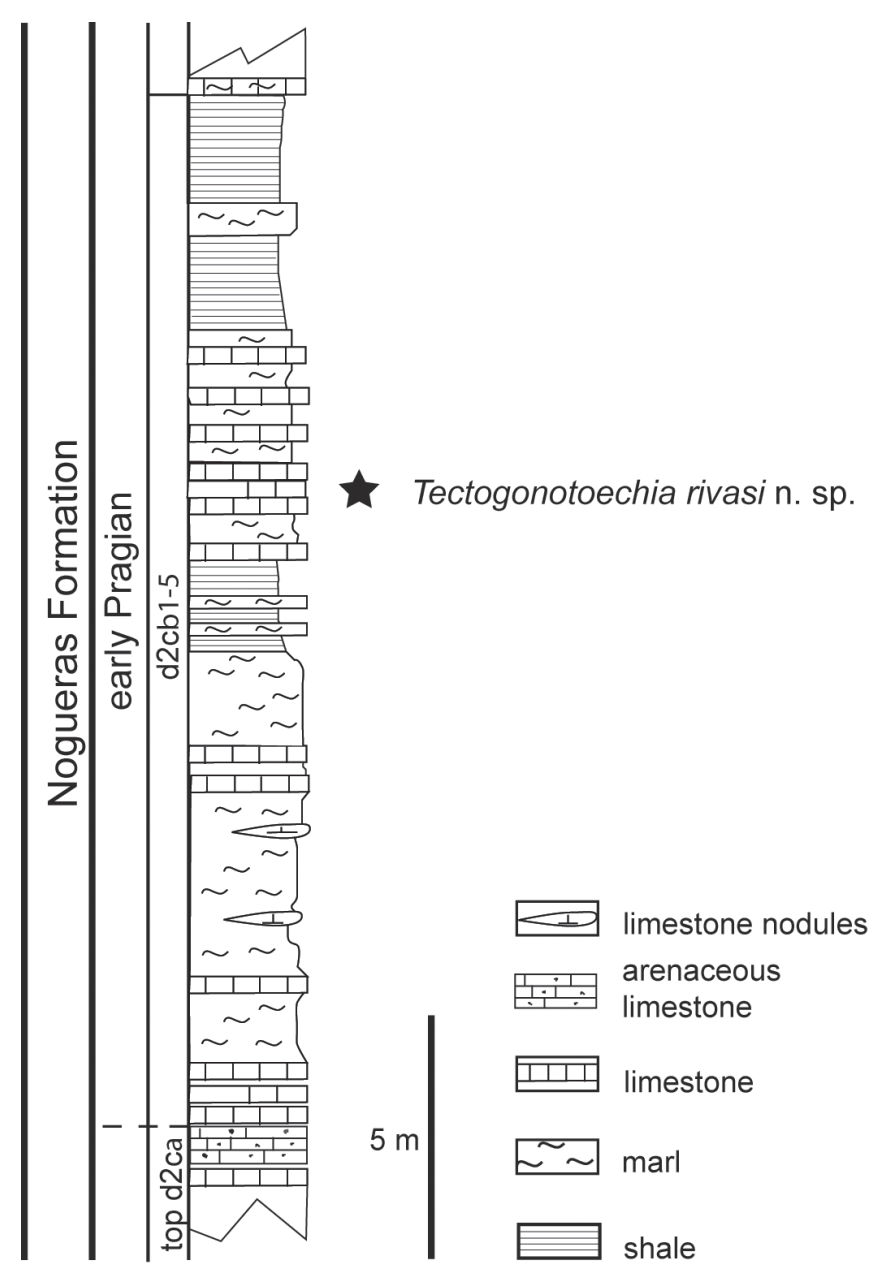

Figure 3. Synthetic stratigraphical column of the upper part of the Nogueras Formation in Santo Domingo Gully, Mezquita de Loscos (province of Teruel, Spain) (based in Dojen, 2005) with the situation of the Tectogonotoechia rivasi $\mathrm{n}$. sp. Stratotype.

Discussion. Differences between Tectogonotoechia and Ancillotoechia Havlíček, 1959, and Aratoechia Havlíček, 1982 were discussed in García-Alcalde (1998). Stenorhynchia Brice, 1981, is also a close genus with a similar external dorsal umbonal furrow and internal morphology, but its median dorsal ridge is a true septum provided by an axial granular calcite sheet (mediotest), which during further ontogeny became moderately thicker by apposition of secondary shell lamellae on both sides of the septum (Brice, 1981: Fig. 1; Savage, 2002: Fig. 717.1); sulcus and fold develop in Tectogonotoechia closer to umbones than in Stenorhynchia. However, it should be made clear that Stenorhynchia diagnosis by Savage (2002: 1062) differs from the original one in important points, i.e. the occurrence of marginal spines, nonexistent according to Brice (1981: 195), and in the start of sulcus and fold at the umbones, instead of at the posterior third or forwards (Brice, 1981). 


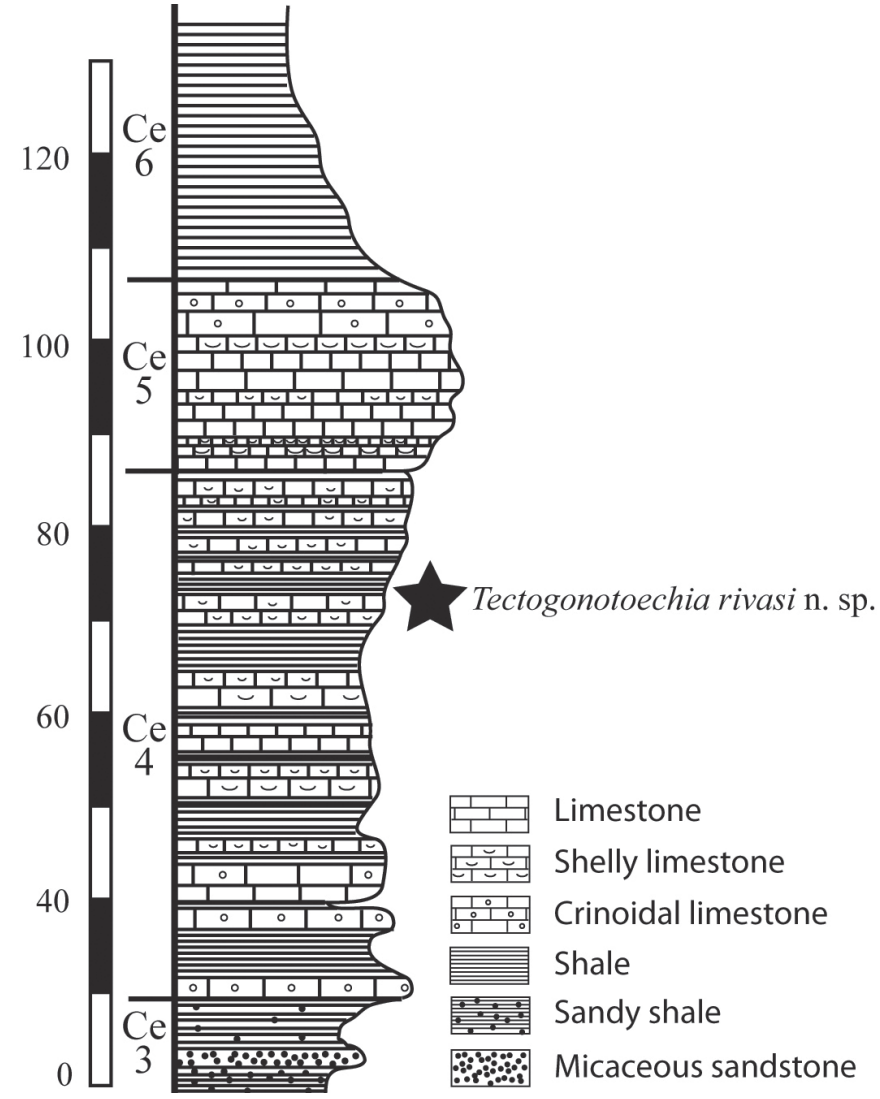

Figure 4. Stratigraphical column of the lower part of the Cercadillo Formation (Members C3, pars, Ce4-Ce5, and Ce6, pars), Eastern Guadarrama, ca. $4 \mathrm{~km} \mathrm{~W} \mathrm{La}$ Riba de Santiuste, between the Cercadillo and Del Agua Creeks (Barahona sheet 434 of the IGME Spain Geological Map, Scale 1:50.000) with location of beds with Tectogonotoechia rivasi $\mathrm{n}$. $\mathrm{sp}$. (based partially in Bultynck \& Soers, 1971).

García-Alcalde (1998) suggested that numerous small Old World Realm, Lochkovian-Pragian rhynchonellids, and tentatively other from upper Pridolian to Lochkovian, would belong to the discussed genus. However, most part of the supposed Tectogonotoechia species are badly known yet, in particular concerning to the occurrence of either a true median septum or a pseudoseptum in the dorsal valve.

\section{Tectogonotoechia rivasi $\mathrm{n}$. $\mathrm{sp}$.}

Figs 3-4, 7-12, Table I

Derivatio nominis. After the Professor Pascual Rivas surname, as an affectionate homage to an excellent researcher and a great friend.

Locus typicus and stratum typicum. Path W Mezquita de Loscos (South of Santo Domingo gully, EIC, Teruel province, East Spain) (Fig. 6). Upper part of the Nogueras Formation, submember d2c $\beta$, lower Pragian (Fig. 3).
Table 1. Tectogonotoechia rivasi $\mathrm{n}$. sp. Measurements of some well preserved selected specimens. Abbreviations: L, $\mathrm{w}, \mathrm{t}$ : length, width, and thickness of the shell; $\alpha$ : apical angle; Nc: Total number of costae on the pedicle valve.

\begin{tabular}{lccccccc}
\hline \multicolumn{1}{c}{ Specimen } & $\mathbf{L}$ & $\mathbf{w}$ & $\mathbf{t}$ & $\mathbf{w} / \mathbf{L}$ & $\mathbf{t} / \mathbf{L}$ & $\boldsymbol{\alpha}$ & $\mathbf{N c}$ \\
\hline Holotype DPO 46821 & 16.4 & 16.7 & 15.9 & 1.02 & 0.85 & $79^{\circ}$ & 23 \\
Paratype DPO 46822 & 14 & 16.9 & 11.3 & 1.21 & 0.81 & $93^{\circ}$ & 21 \\
Paratype DPO 46826 & 13.5 & 14.9 & 11.5 & 1.10 & 0.85 & $92^{\circ}$ & 23 \\
Paratype DPO 46827 & 13.2 & 15 & 9.1 & 1.14 & 0.69 & $91^{\circ}$ & 23 \\
Paratype DPO 46828 & 13.5 & 13 & 13.5 & 0.96 & 1 & $90^{\circ}$ & 21 \\
Paratype DPO 46829 & 12.7 & 14 & 11.1 & 1.10 & 0.87 & $102^{\circ}$ & 19 \\
Paratype DPO 46832 & 11 & 11.9 & 7.7 & 1.08 & 0.70 & $96^{\circ}$ & \\
Paratype DPO 46833 & 11.4 & 12.4 & 6.7 & 1.09 & 0.59 & $85^{\circ}$ & 21 \\
Paratype DPO 46834 & 9.8 & 10.4 & 6.2 & 1.06 & 0.63 & $88^{\circ}$ & 19 \\
Paratype DPO 46835 & 11 & 11.2 & 8.9 & 1.02 & 0.81 & $99^{\circ}$ & 21 \\
Topotype DPO 46843 & 15 & 15.4 & 10.5 & 1.03 & 0.70 & $82^{\circ}$ & 19 \\
Topotype DPO 46848 & 13.3 & 14 & 9.4 & 1.05 & 0.71 & $90^{\circ}$ & 23 \\
Topotype DPO 46853 & 10.5 & 12 & 7 & 1.14 & 0.67 & $80^{\circ}$ & 19 \\
Topotype DPO 46854 & 9 & 10.7 & 4.2 & 1.19 & 0.47 & $86^{\circ}$ & 19 \\
Topotype DPO 46895 & 14.7 & 15.7 & 12.2 & 1.07 & 0.83 & & 25 \\
DPO 46905 & 14.4 & 16.1 & 10.8 & 1.12 & 0.75 & $93^{\circ}$ & 25 \\
DPO 46906 & 13.6 & 14.2 & 10.6 & 1.04 & 0.78 & $95^{\circ}$ & 25 \\
DPO 46907 & 13 & 13 & 9.2 & 1 & 0.71 & $88^{\circ}$ & 23 \\
DPO 46908 & 13.2 & 14.8 & 9 & 1.12 & 0.68 & $94^{\circ}$ & 25 \\
DPO 46920 & 13 & 16.5 & 11.6 & 1.27 & 0.89 & & 25 \\
DPO 46921 & 12.6 & 14.3 & 10.6 & 1.13 & 0.84 & & 25 \\
DPO 46916 & 12.5 & 13 & 9 & 1.04 & 0.72 & & 21 \\
DPO 46927 & 17 & 17 & 14.2 & 1 & 0.84 & $100^{\circ}$ & 23 \\
\hline & & & & & & & \\
\hline
\end{tabular}

Material. A hundred and three variably preserved specimens, in generally bivalved shells, but more or less crushed and exfoliated. Holotype DPO 46821 (Figs 8a1a5) and fourteen paratypes, DPO 46822-46835 (DPO 46824, 46826-46827, 46829, 46831, 46833-46835, figured, see Fig. 8), of the locus and stratum typicum (Figs 3, 6). Sixty generally badly preserved topotype specimens, DPO 46836-46854, 46856-46896 (DPO 46854, Figs 8m1m4, DPO 46891, Fig. 8j). Thirteen, variably preserved specimens, DPO 46905-46908, 46918-46926 (DPO 46907, Figs 8k1-k4) from the Fuente de Nogueras, at the village of Nogueras (Fig. 6), upper part of the Nogueras Formation, lower Pragian. Five, badly preserved specimens, DPO 46898-46902, from the Carniceros section. Four, variably preserved specimens, DPO 46914-46917 from the Las Viñas section, along the Cámaras Creek. Five, variably preserved specimens, DPO 46909-46913 from the Escalambreras section. One, well preserved specimen, DPO 46927 (Figs 811-14) from the Eastern Guadarrama, Bacho de La Velilla section (Figs 1, 4). 


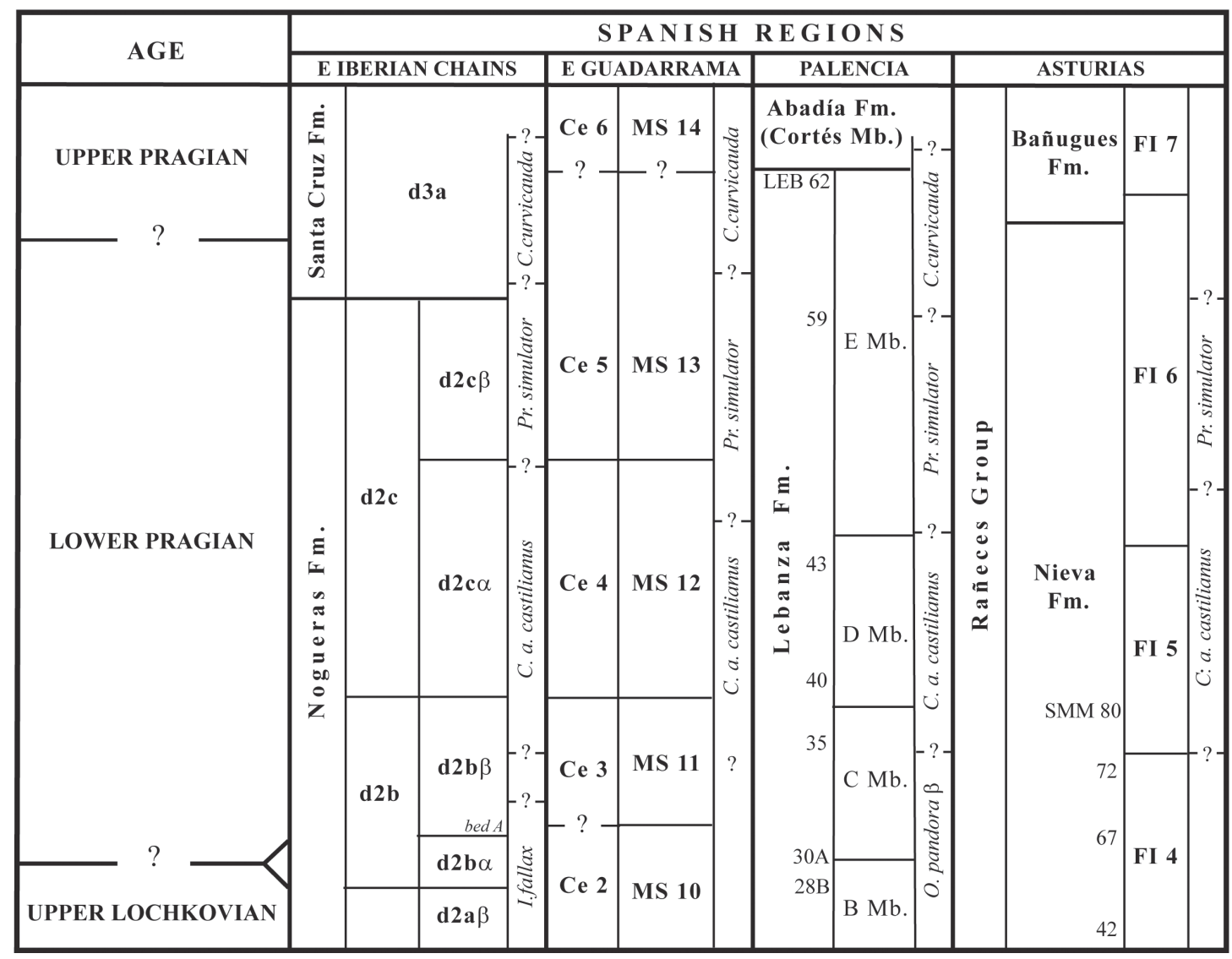

Figure 5. Correlation of the Celtiberian (EIC and EG) and Cantabrian Mountains (Palencia, and Asturias) Pragian units. Abbreviations: C: Caudicriodus; C. a: Caudicriodus angustoides; Pr: Praelatericriodus; I: Icriodus; O: Ozarkodina; FI: Faunal Intervals (García-Alcalde, 1996). After data from Sommer (1965), Bultynck (in Bultynck \& Soers, 1971), Bultynck (1976), García-Alcalde et al. (1990), Carls et al. (1993), Carls (1999), Carls \& Valenzuela-Ríos (1999), García-López \& Sanz-López with contributions by Sarmiento (2002), García-López \& Sanz-López (2002), García-Alcalde (2014), and herein.

Diagnosis. Size large for the genus, outline subpentagonal, strongly dorsibiconvex shell with four angular costae on the dorsal fold and three angular costae in the ventral sulcus. Flanks of ephebic specimens with nine to ten angular costae.

Description. Shell large (largest specimen in the collection: 17 to $18 \mathrm{~mm}$ ), sligthly transverse (average of the width/length, w/L, ratio: 1.09 for forty four measurements), thick (average of the thikness/length, t/L, ratio: 0.4 for forty measurements) (Fig. 7, Table 1), subpentagonal outline, strongly dorsibiconvex in lateral profile (i.e. Figs $8 \mathrm{a} 4,8 \mathrm{~d} 4,8 \mathrm{e} 3,814$ ), maximum width at the second third of length (average: $64 \%$ of length, for nineteen measurements). The brachial valve attains the greatest convexity at the umbo, where a marked longitudinal furrow (Fig. 8h) replaced by a fold toward the front occurs; maximum thickness at the anterior part of shell or slightly posterior to it. Ventral beak well-developed, pierced by a relatively large, permesothyrid, circular foramen bounded basally by short and strong conjunct deltidial plates (Figs 8a2, 8f2, 8g2, 8k2); beak angle erect to incurved, projected only a slight distance beyond the posterior of the brachial valve; average of apical angle: $90^{\circ}$ (for nineteen measurements). Ventral interarea defined by relatively sharp beak ridges. Fold and sulcus well developed, beginning in front of beaks (between 15 to $58 \%$ of length; average for nineteen measurements: $26 \%$ ); fold of trapezoidal section, sulcus shallow, relatively flat to gently concave, widening and deepening forwards, diverging 26 to $40^{\circ}$ (average for nineteen measurements: $34^{\circ}$ ) occupying a great part of width anteriorly (between 45 to $78 \%$; average for nineteen measurements: $53 \%$ of width); the sulcus ends in a trapezoidal, high, strongly deflected tongue, vertical to postero-dorsally directed; anterior commissure uniplicate and strongly serrate. Flanks narrow, with short lateral endings turning abruptly to commissures to form an obtuse angle among them. Ornamentation consistent of angular radial costae, strongly indented at the commissures, with interspaces similar; 


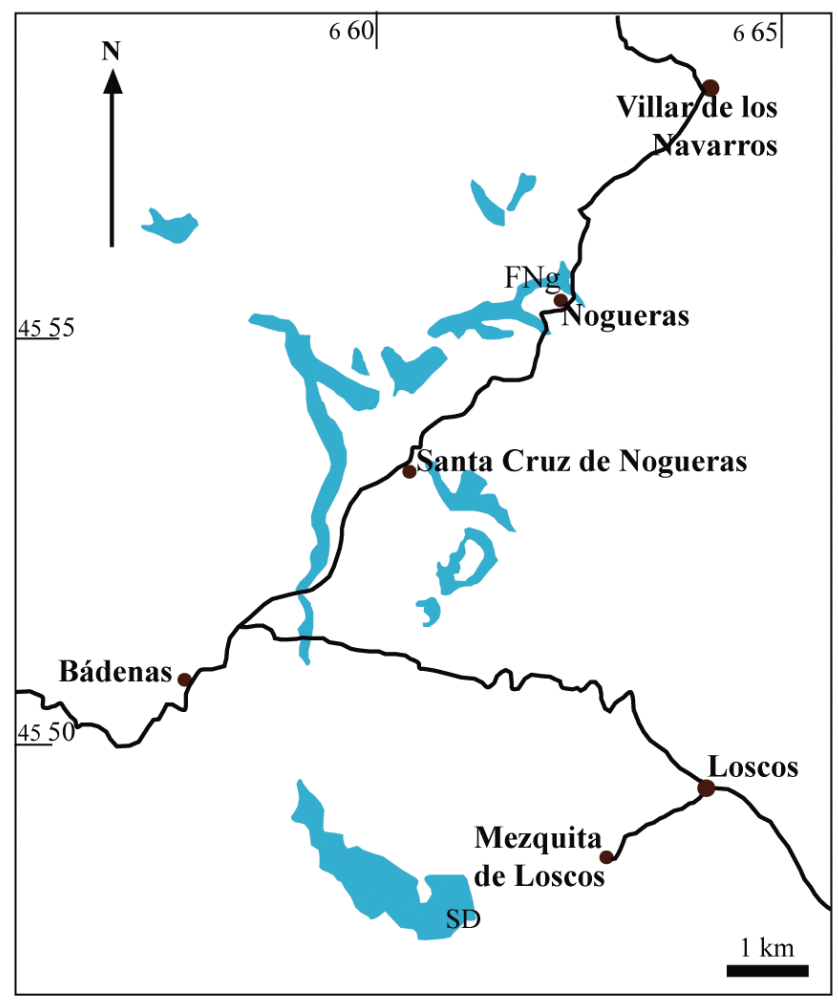

Nogueras Fm. (modified from Carls, 1987)

SD: Santo Domingo gully; FNg: Fuente de Nogueras.

Figure 6. Geographical and geological location of the type locality (SD, Mezquita de Loscos) and other localities of the EIC where Tectogonotoechia rivasi $\mathrm{n}$. $\mathrm{sp}$. occurs.

four costae on the fold of the brachial valve and three in the sulcus of the pedicle valve (for more than $90 \%$ of the observed specimens); exceptionally the sulcus bears five (one specimen) or three (two specimens) costae on the fold, and four or two on the sulcus; the median costae on fold are inserted between the external ones, and start at the bottom of a longitudinal umbonal furrow a little ahead the apex, while the external fold costae begin in the valve apex itself (Fig. 8h); forward, the internal pair rise to turn higher and stronger than the external one; the external costae on fold have markedly asymmetric flanks. Sulcus with the median costa slightly stronger than the others; the sulcus is clearly bounded by costae stronger than the lateral, but they are settled distally in a lower level than the next pair of lateral costae; from this fact, the sulcus bounding costae could be interpreted likewise as parietal. Total number of costae on the pedicle valve varies from eleven to twenty five (average for 54 measurements: 21); they are slightly curved postero-laterally, and the two or three more external pairs of radial ribs are exceedingly fine, obsolescent; only a bifurcation of costae has been observed from more than a hundred of specimens. Concentric ornamentation consistent of a few, prominent, irregularly spaced growth
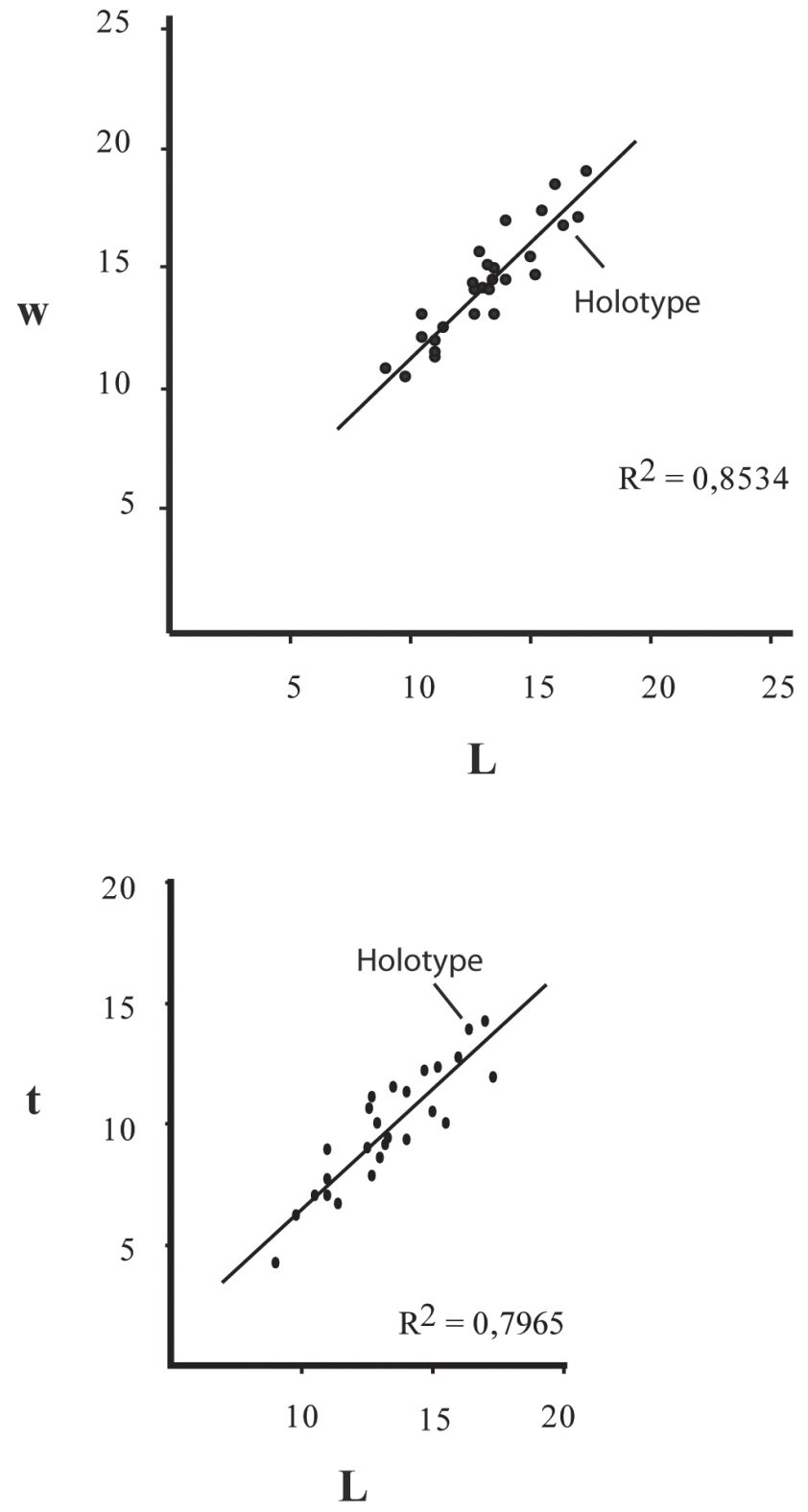

Figure 7. Tectogonotoechia rivasi $\mathrm{n}$. $\mathrm{sp}$. width/lenght (w/L) ratio, and thickness/length $(\mathrm{t} / \mathrm{L})$ ratio dispersion diagrams.

lines (Fig. 8g1), and numerous, much finer lines parallel to the latter, visible on median magnifications.

Acetate peels of serial sections show dental plates strong, short, reaching less than half the length of valve, with vertical walls, extending below the bounding costae of sulcus; umbonal cavities free in young specimens (Fig. 9) but nearly completely filled in adults by secondary shell (Figs 10-11); the dental plates support unmodified, strong teeth inserted in deep dental sockets; faint outer socket ridges and strong, high inner socket ridges (Fig. 11) the latter ones with distal ends articulated at the base of teeth in shallow crural fossettes (Figs 9-11); denticular cavities developed usually to receive the ventral edge of the outer socket ridges (Figs 10-11). 


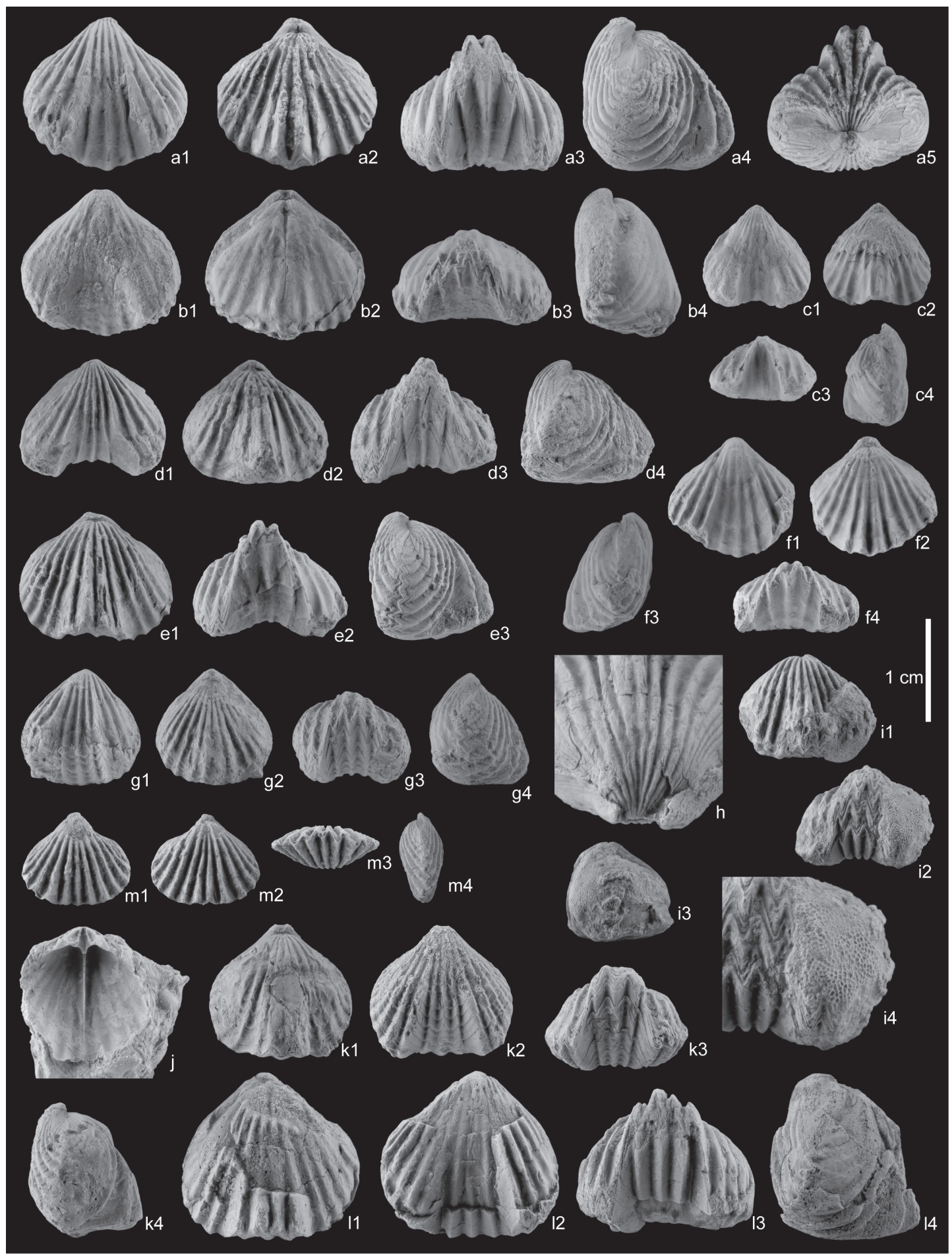

Figure 8. Tectogonotoechia rivasi $\mathrm{n}$. sp. (a1-a5) Holotype DPO 46821, ventral, dorsal, anterior, lateral, and posterior views. Nogueras Formation, Mezquita de Loscos, Santo Domingo gully section. (b1-b4) Paratype DPO 46827, ventral, dorsal, anterior, and lateral views. Same as befote. (c1-c4) Paratype DPO 46834, ventral, dorsal, anterior, and lateral views. Same as before. (d1d4) Paratype DPO 46829, ventral, dorsal, anterior, and lateral views. Same as before. (e1-e3) Paratype DPO 46826, dorsal, anterior, and lateral views. Same as before. (f1-f4) Paratype DPO 46833, ventral, dorsal, lateral, and anterior views. Same as before. (g1-g4) Paratype DPO 46835, ventral, dorsal, anterior, and lateral views. Same as before. (h) Paratype DPO 46824, enlarged partial postero-dorsal view showing the median umbonal dorsal furrow. Same as before. (i1-i3) Paratype DPO 46831, dorsal, anterior, and lateral views. (i4) enlargement of the left side of the i2 view showing a epizoan (Bryozoan) covering a part of the anterior commissure. (j) Topotype DPO 46891, internal dorsal view. Same as before. (k1-k4) DPO 46907, ventral, dorsal, anterior, and lateral views. Nogueras Formation, Fuente de Nogueras (Teruel). (11-14) DPO 46927, ventral, dorsal, anterior, and lateral views. Cercadillo Formation, Eastern Guadarrama, Bacho de La Velilla section. (m1m4) Topotype DPO 46854, ventral, dorsal, anterior, and lateral views of a young specimen. Santo Domingo gully section. 
0.2

0.8

1.5

1.7

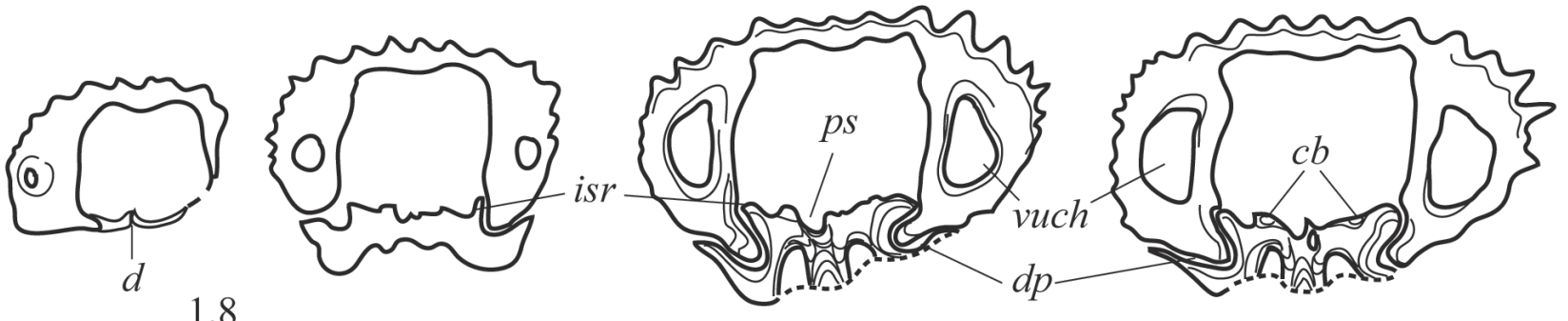

1.8

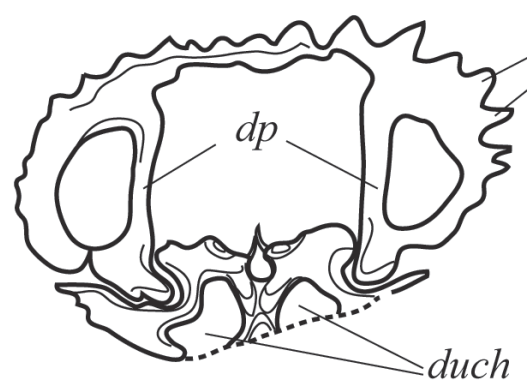

2.3

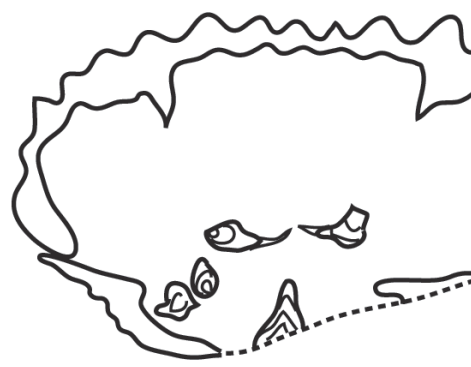

2.75

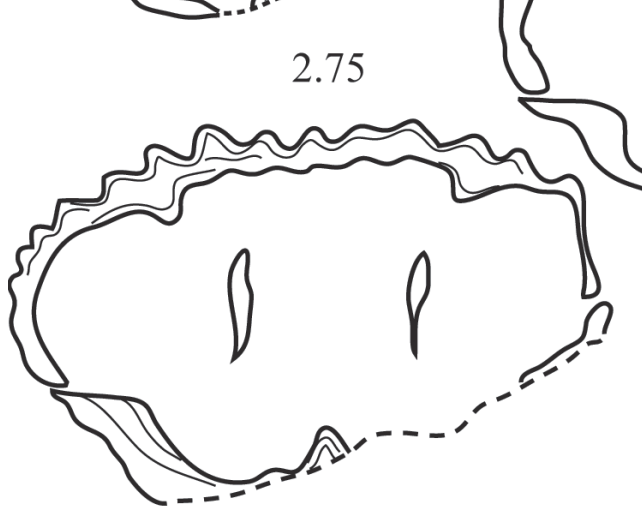

3.3

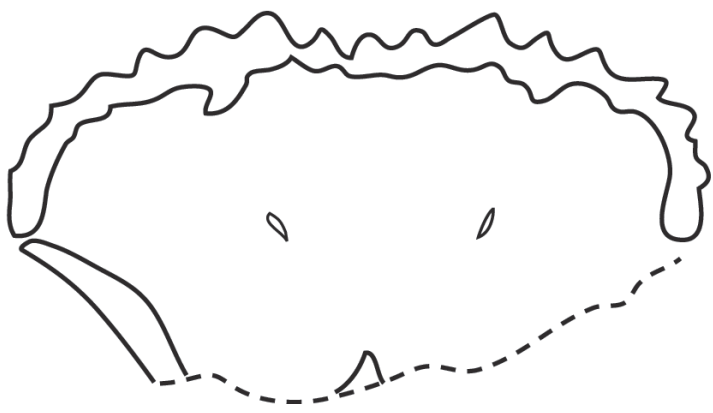

2.1

2.2

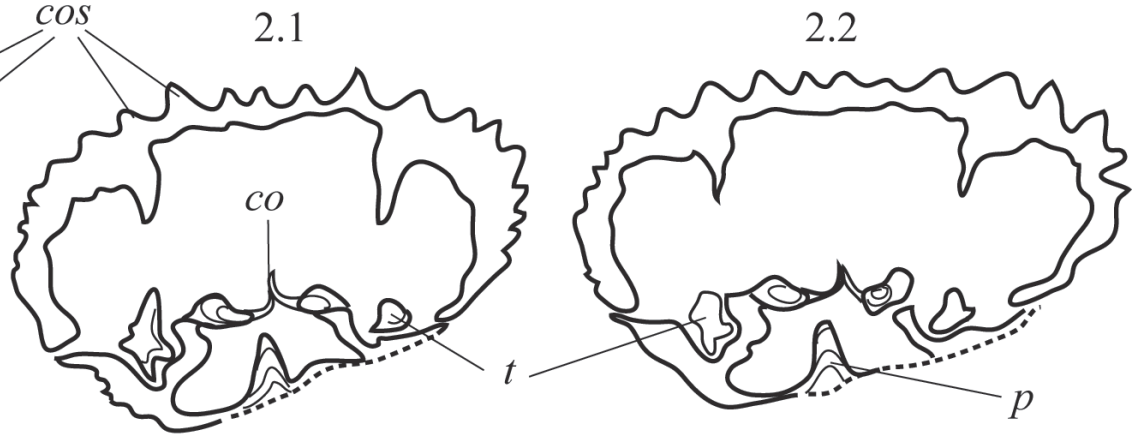

2.7

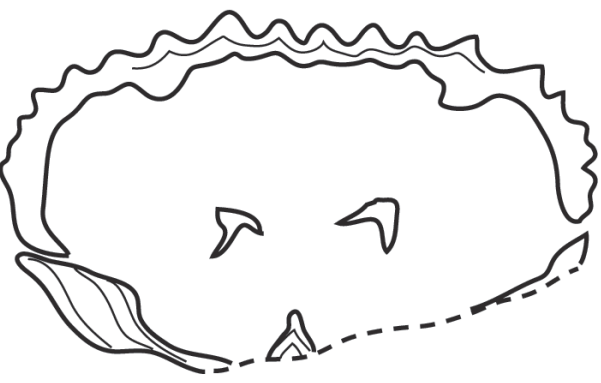

3.1

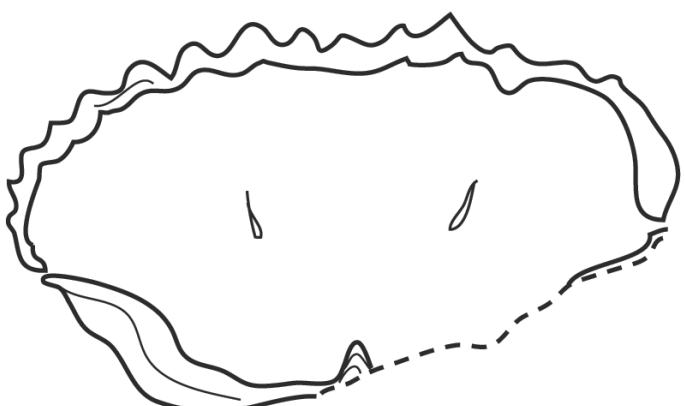

$5 \mathrm{~mm}$

Figure 9. Tectogonotoechia rivasi n. sp. Serial sections of a relatively young specimen. DPO 46855, with umbonal cavities free of callus. Abbreviations for this figure and Figs 10-11. cb: crural bases; co: inner hinge plates (connectivum); cos: costae; cr: crurae; d: deltidium; dp: dental plates; duch: dorsal umbonal chambers; isr: inner socket ridges; p: seudoseptum; ps: pseudoseptalium; t: teeth; vuch: ventral umbonal chambers. 
0.2

0.3

0.7

0.85

1.1

1.2

1.4
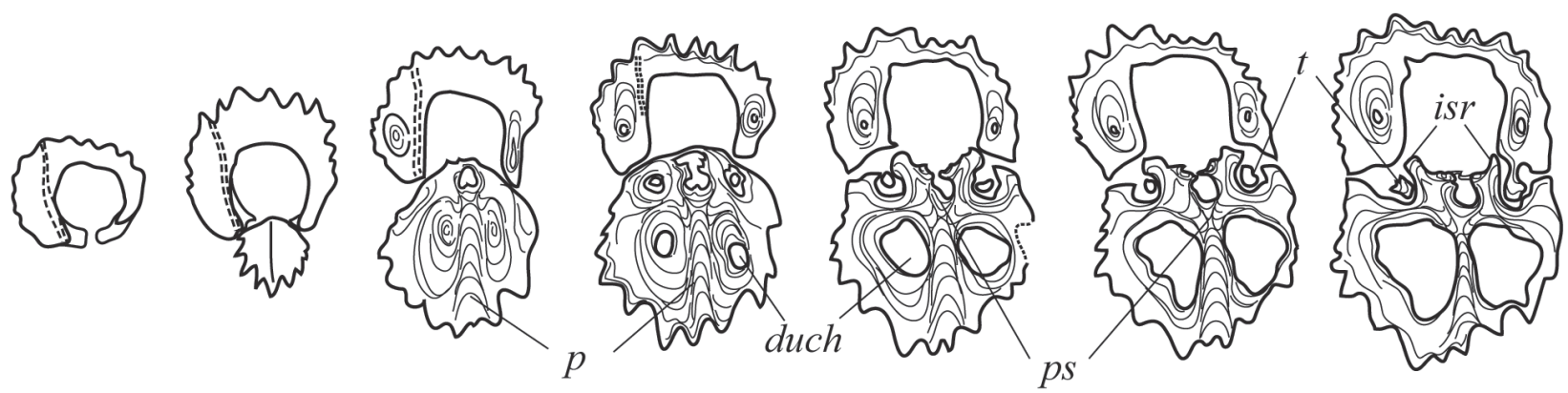

1.5

1.9

2.1

co

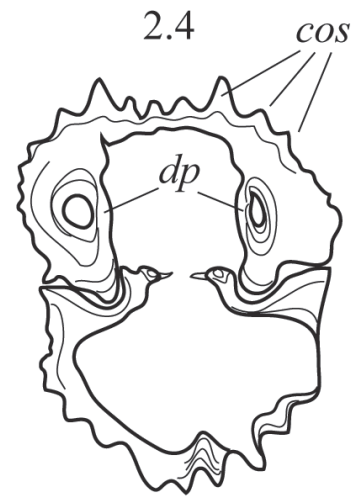

2.7
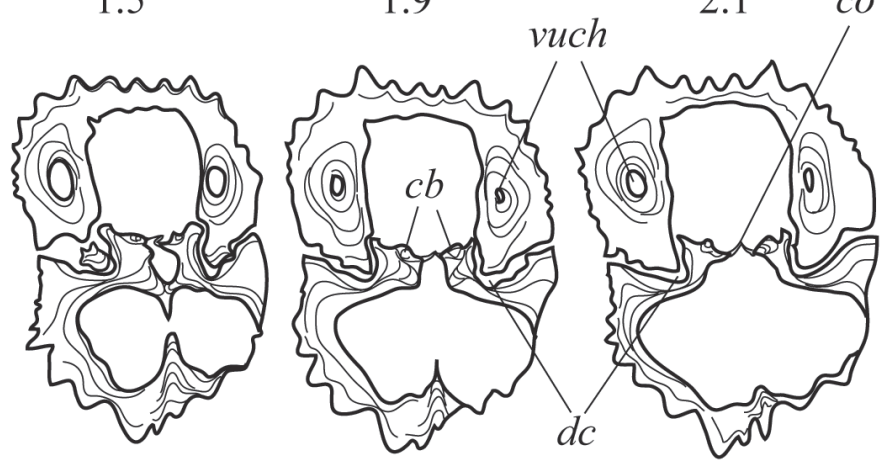

3.7

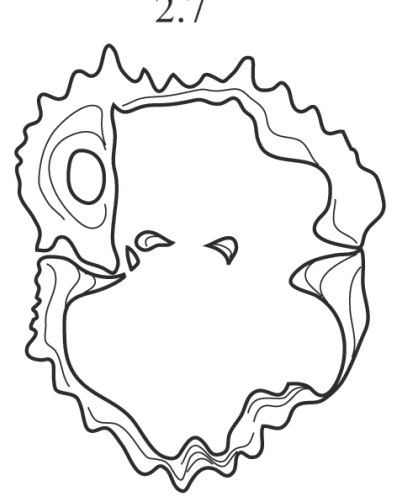

3.5
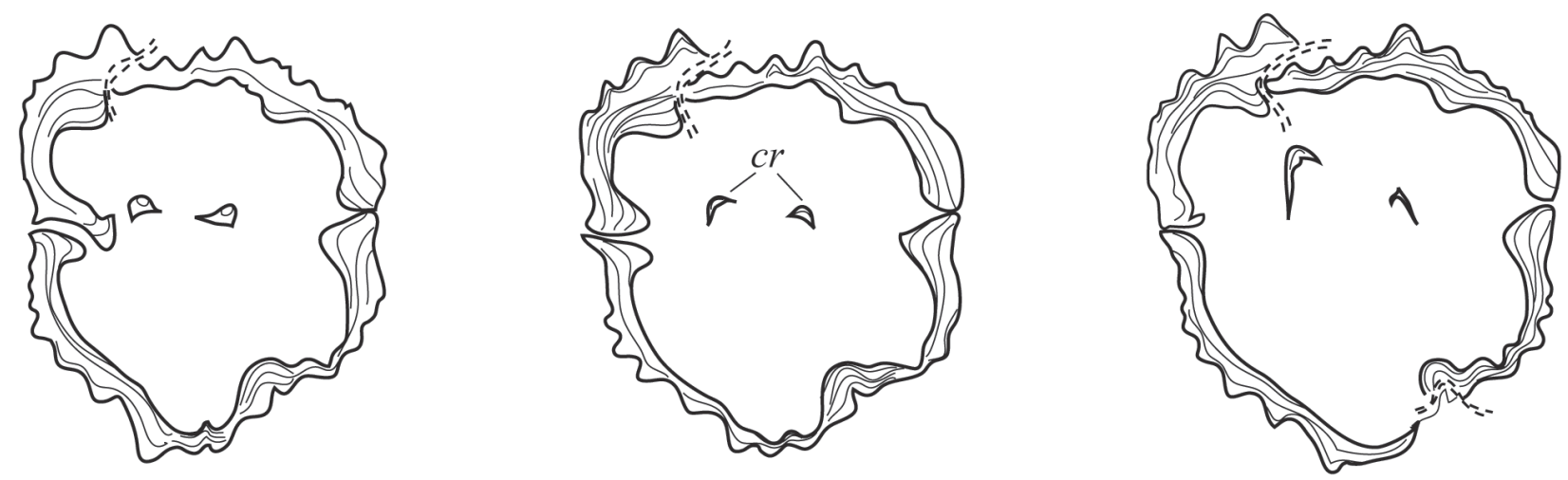

3.9

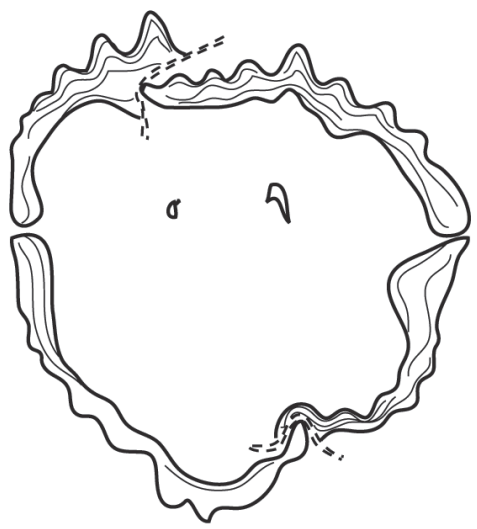

Figure 10. Tectogonotoechia rivasi n. sp. DPO 46861. Serial sections of a mature, slightly damaged specimen. Dotted lines: shell fractures. 
By calcination a specimen produced a good steinkern showing the internal ventral characters. The ventral muscle field is fairly well impressed, rather long ( $1 / 2$ of length of valve or more) with adductor scar longitudinally oval, limited posterolaterally by narrow adjustor scars and anterolaterally by relatively large, trapezoidal diductor scars (Fig. 12), and it is bounded laterally by the base of the dental plates.

Massive cardinal plate formed by flattened, horizontal outer hinge plates and very fine inner plates joined forward in a roofed over, angular cover (connectivum) open posteriorly by an oval dorsal foramen; the inner and outer hinge plates are separate by prominent crural bases united to fused crural plates that are, in turn, supported by a thick pseudoseptum; the septiform ridge weakens and tapers forward, reaching sometimes almost the anterior of valve (Figs 9-11). The fused crural plates define a reduced, troughlike pseudoseptalium roofed over by the connectivum and variably obscured by deposits of shell material. The connectivum reaches usually further on the cardinal plate, joining the proximal part of crurae (Fig. 11). Crurae strong, antero-ventrally directed, reaching $1 / 3$ of length, with well-developed, acute crural points. The dorsal muscle field bears narrow and short adductor scars limited laterally by relatively high, rounded muscle-bounding ridges (Figs 9, 11).

Ontogeny. The sample at hand does not include brephic to early neanic specimens. However, specimens belonging to the late neanic, early ephebic, typical adults, and senescent development stages allow to recognize growth trends in the taxon. Youngest shells would be biconvex with sharp commissures turning to be strongly dorsibiconvex, with abrupt flanks in adults; sulcus and fold in youngs are scarcely developed and start far from apex ( $50 \%$ of length of valve or furthermost) turning to develop nearer from beaks in adults. Ventral tongue is inexistent or very low, antero-ventrally directed in youngs, and turns to be vertical to postero-dorsally directed in adults. The ventral beak is long and narrow, with an apical angle less than $90^{\circ}$ and a beak angle straight to inclined in young, and turns to be shorter and larger with an apical angle of $90^{\circ}$ or more and a beak angle erect to incurved in adults (compare Fig. $8 \mathrm{~m}$ with the other figures). The number of costae on fold (four) and sulcus (three) is a very consistent feature in the species along the ontogeny, but the number of lateral costae rises from ten to twelve in young specimens to more than twenty in adults. Finally, immature specimens have well-developed, free umbonal cavities and clear defined dental plates (Fig. 9) whereas normal ephebic individuals have umbonal cavities filled by secondary shell and badly defined, thick dental plates (Figs 10-11).

Epizoans. The individuals of the bottom communities in the upper part of the Nogueras Formation along the EIC share out the character of being encrusted and bored by a varied epizoan fauna, representing different symbiotic interactions and probably indicating the permanent risk of the epizoan to be buried in an unstable, soft substrate. Tectogonia rivasi $\mathrm{n}$. $\mathrm{sp}$. has also been the settlement of epizoans (at less, twenty one specimens of the total sample composed by ca. a hundred of shells, were colonized in life or post-mortem). Most part of the recognized T. rivasi n. sp. epizoans are small bryozoan colonies (Figs 8i1-i4), but cornulitids, auloporid tabulates, and crinoids also occur. Several probably bryozoan borings have also been noticed on serial sections of the dorsal valve of a specimen (Fig. 11, sections 3.3 to 4.45 ).

Discussion. Tectogonotoechia rivasi $\mathrm{n}$. sp. differs from the type-species of the genus, T. tectogonia GarcíaAlcalde, 1998 in the transverse shape, larger size, lateral profile strongly dorsibiconvex, higher ventral tongue, and more developed sulcus and fold beginning nearer from apex. Stenorhynchia subpareti (Oehlert, 1884) and Rhynchonella cypris d'Orbigny, 1850 are smaller with less radial costae; besides, the cardinalia of the former species bears a true median septum supporting the septalium, as in Trigonirhynchia and other Rhynchotrematoidea, and the latter species has sharper commissures and unknown internal structure.

Distribution. The studied species is largely represented along the Celtiberian region. In the EIC (Figs 1-2,6) it is usually abundant at the upper part of the Nogueras Formation (upper part of the $\mathrm{d} 2 \mathrm{c} \alpha$ submember and $\mathrm{d} 2 \mathrm{c} \beta$ submember), of the lower Pragian (Fig. 3). It occurs also in less abundant numbers in levels $\mathrm{Ce} 4$ and $\mathrm{Ce} 5$ (Bultynck \& Soers, 1971) (=MS12-13, Sommer, 1965; Carls \& Valenzuela-Ríos, 1999) of lower Pragian age in EG (Figs 1, 4). The Guadarrama forms were possibly identified previously by Bultynck (in Bultynck \& Soers, 1971: 10, and Fig. 9) as Stegerhynchus nymphus (Barrande, J., 1847). Camarotoechia ? cypris (d'Orbigny, 1850) determined by Binnekamp (1965) along the Lebanza Formation (Members B to E, Fig. 5) in Palencia (Cantabrian Mountains) (Fig. 1) could embrace several different Tectogonotoechia species, including the studied herein, but the collections at hand are not abundant nor well preserved enough to guarantee it.

\section{CONCLUSIONS}

The lower Pragian of the Celtiberian region (upper part of the Nogueras Formation, and lower third of the Cercadillo Formation) records important bottomlevel fossil associations, belonging to sub- to inter-tidal environments that represent the beginning of a rhytmothem detectable along the EIC and Eastern Guadarrama and 

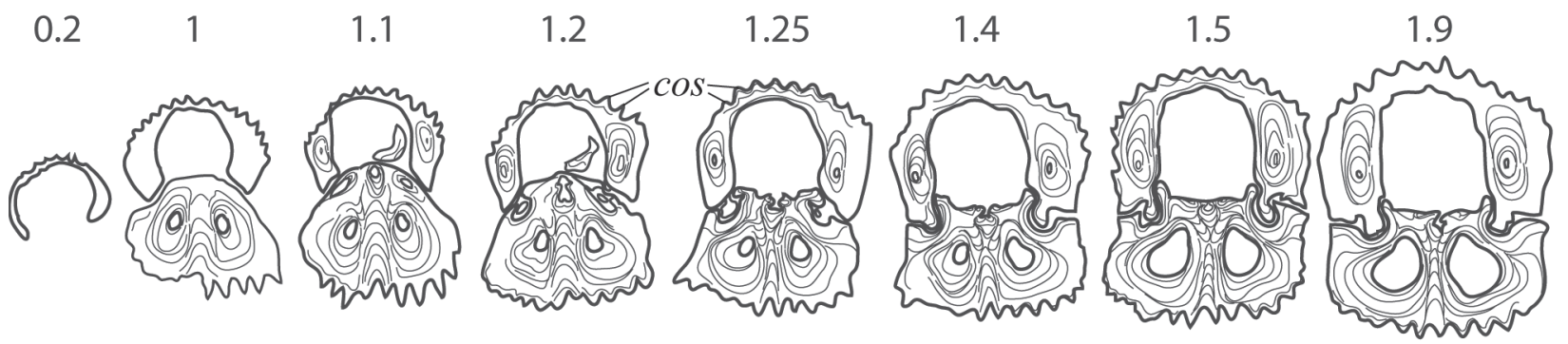

2.1

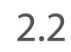

2.5

2.8

3.1

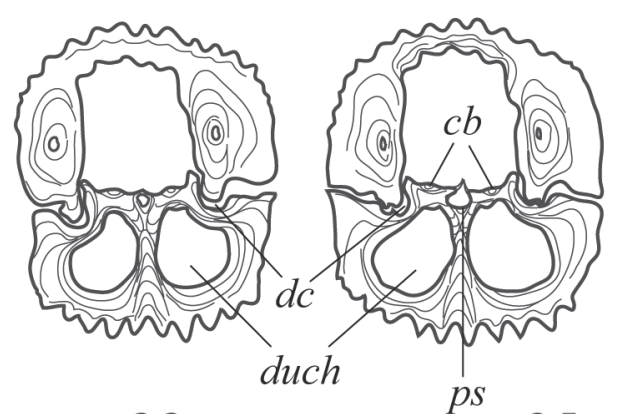

3.3

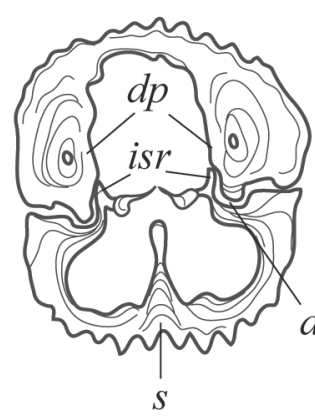

4

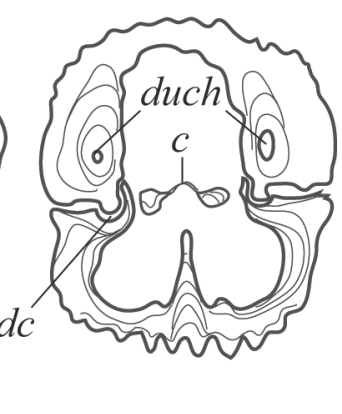

.

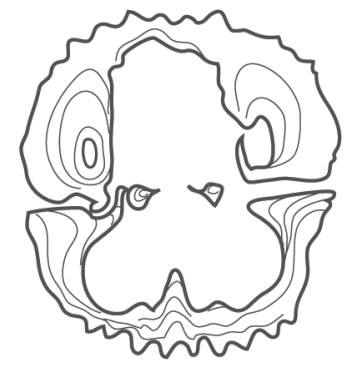

4.2
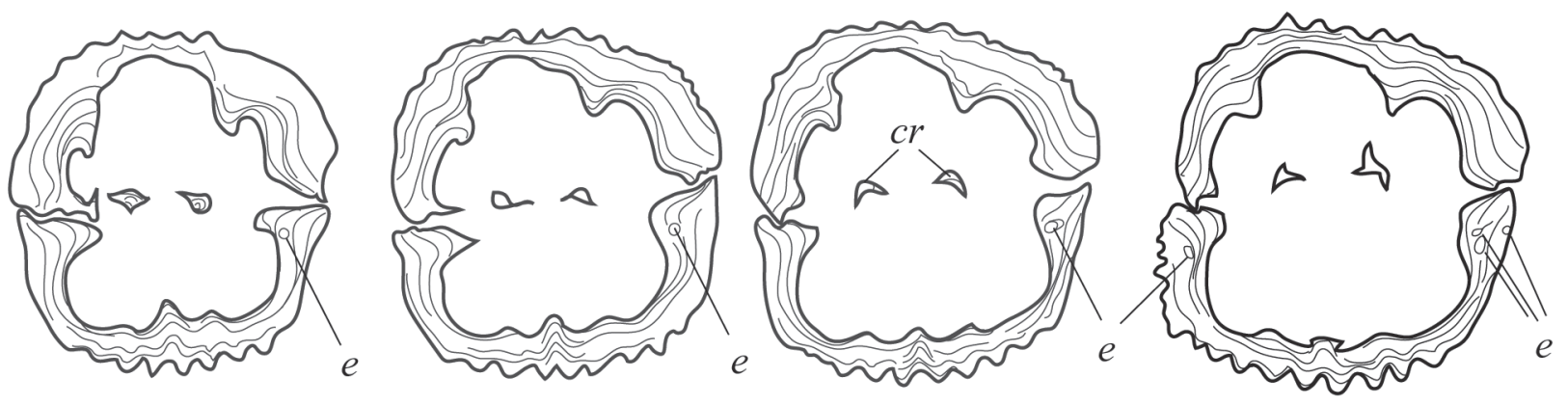

4.3

4.35

4.4

4.45

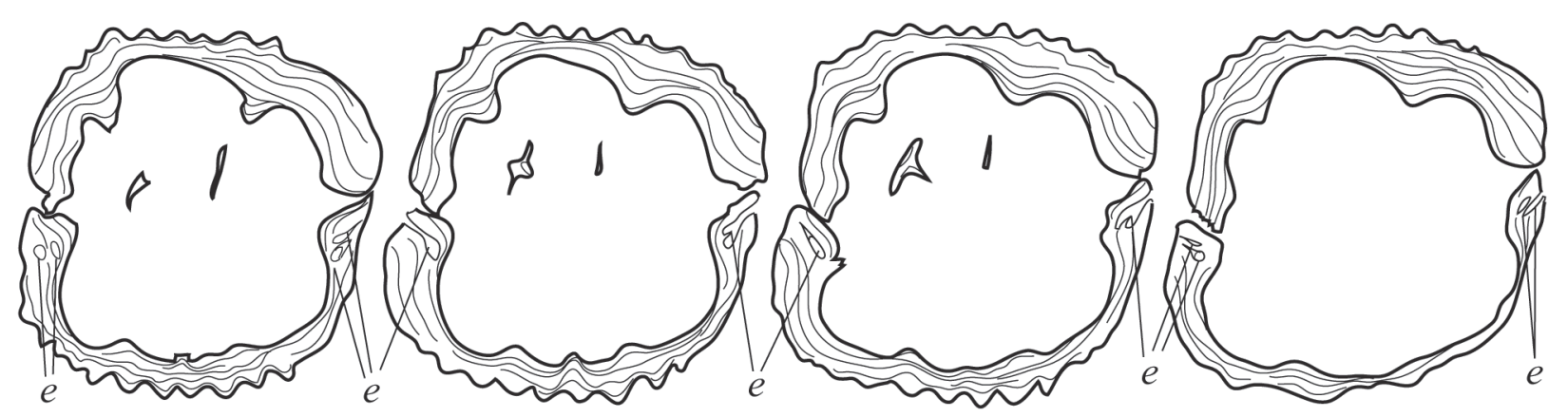

$5 \mathrm{~mm}$

Figure 11. Tectogonotoechia rivasi n. sp. DPO 46893. Serial sections of a mature shell, with dorsal valve bored, possibly post-mortem, by unknown organisms, possibly Bryozoan colonies near the commissure. e: epizoan borings. 


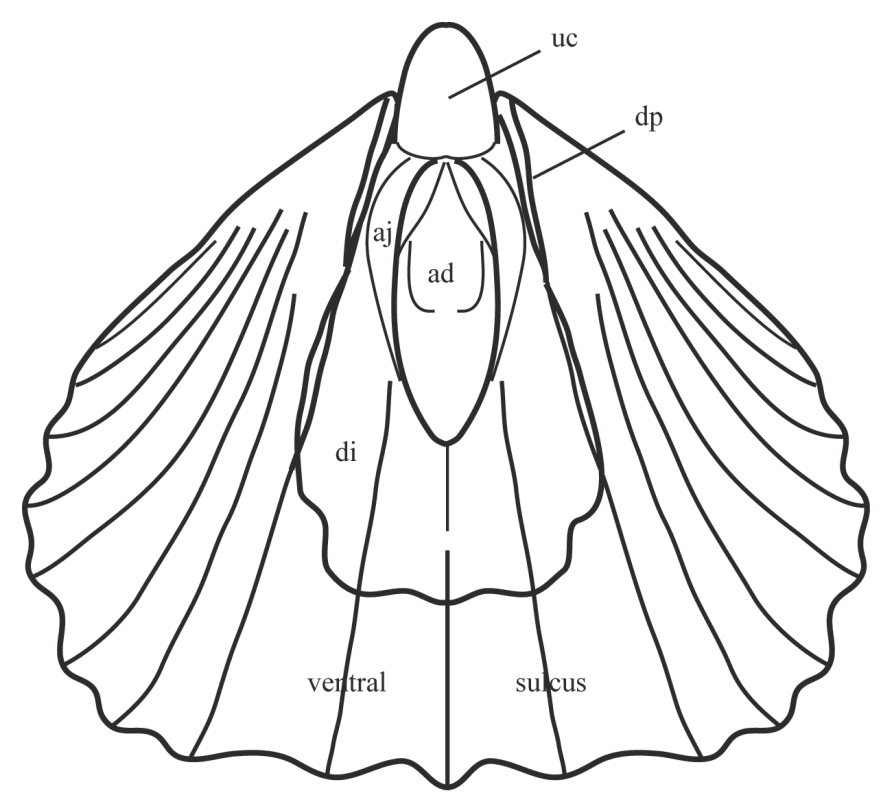

$10 \mathrm{~mm}$ ontogeny in profile, convexity, apical angle, beak angle, total number of costae, and infilling of internal cavities. Epizoans were abundant in the fossil association where the new species occurs. In particular, ca. $20 \%$ of the T. rivasi n. sp. specimens were incrusted in life or post-mortem by small bryozoan, solitary corals, and tabulates. At least a specimen shows fine and long borings near the commissure probably due to bryozoans.

\section{ACKNOWLEDGEMENTS}

This paper is a contribution to IGCP Project 596, Climate change and biodiversity patterns in the Mid-Palaeozoic (Early Devonian to Late Carboniferous).

The author thanks Prof. Miguel V. Pardo, of the University of Valencia, and an anonymous referee for the critical reading of a draft of this note and for the suggested improvements.

\section{REFERENCES} Ventral muscle field (slightly idealized) of the specimen DPO 46873. Abbreviations: ad: adductor scar; aj: adjustor scar; di: diductor scar; dp: dental plate; uc: umbonal cavity.

reaching probably eastern Armorica, in France (Carls, 1988). Brachiopods, bryozoans, solitary rugose corals, tabulates, trilobites, ostracods, and other macrofaunal and microfaunal elements are diverse and abundant and embrace numerous taxa that allow good correlations along the Celtiberian-Armorican basin. An important fraction of these taxa is waiting to be described (GarcíaAlcalde \& Herrera, 2015). A new rhynchonellid species, Tectogonotoechia rivasi $\mathrm{n}$. $\mathrm{sp}$. has given us the chance to pay tribute to Professor Pascual Rivas, of the University of Granada on the occasion of his retirement. The new species has the general external morphology of many trigonirhynchiid (Superfamily Rhynchotrematoidea) rhynchonellids, i.e. a strongly dorsibiconvex, costate shell with subangular costae strongly indented at the commissures with no marginal spines, four costae on the fold, and three in the sinus, and a more or less marked longitudinal furrow on the dorsal umbo. The dorsal interior, however, clearly differs from that superfamily due to the occurrence of a pseudoseptum supporting a pseudoseptalium. This critical feature compel us to assign T. rivasi $\mathrm{n}$. sp. to the Superfamily Ancystrorhynchoidea, in the Family Iberirhynchiidae. T. rivasi n. sp. is a largesized form for the genus, with marked changes along the
Barrande, J. 1847. Über die Brachiopoden der silurischen Schichten von Böhmen. Naturwissenschaftlichen Abhandlungen. I Band. W. Haidinger. Wien, 357-475.

Binnekamp, J. 1965. Lower Devonian brachiopods and stratigraphy of North Palencia (Cantabrian Mountains, Spain). Leidse Geologische Mededelingen, 33, 1-62.

Brice, D. 1980. Les brachiopodes Rhynchonellida et Terebratulida. In: Les Schistes et Calcaires de l'Armorique (Dévonien Inférieur. Massif Armoricain). SédimentologiePaléontologie-Stratigraphie, (coordinateur Plusquellec, Y.). Mémoires de la Société Géologique et Minéralogique de Bretagne, 23, 233-242.

Brice, D. 1981. Les brachiopodes Pentamerida, Rhynchonellida et Terebratulida. In: La Tranchée de La Lezais, Emsien Supérieur du Massif Armoricain. Sédimentologie, Paléontologie, Stratigraphie, (coordinateurs Morzadec, P., Paris, F. \& Racheboeuf, P.). Mémoires de la Société Géologique et Minéralogique de Bretagne, 24, 193-217.

Bultynck, P. 1976. Le Silurien Supérieur et le Dévonien Inférieur de la Sierra de Guadarrama (Espagne Centrale). Troisième partie: elements icriodiformes, pelekysgnathiformes et polygnathiformes. Bulletin de l'Institut royal des Sciences Naturelles de Belgique, 49, 1-74.

Bultynck, P. \& Soers, E. 1971. Le Silurien supérieur et le Dévonien inférieur de la Sierra de Guadarrama (Espagne Centrale). Première partie: stratigraphie et tectonique. Bulletin de l'Institut royal des Sciences Naturelles de Belgique, 47, 1-22.

Carls, P. 1982. Das kantabrische Devon und der Iberoarmorikanische Bogen aus keltiberischer sicht. In: 
Subsidenz-Entwicklung im Kantabrischen Variszikum und an Passiven Kontinentalrändern der Kreide. Teil 1.Variszikum", (eds Kullmann, J., Schönenberg, R. \& Wiedmann, J.). Neues Jahrbuch für Geologie und Paläontologie Abhandlungen, 163, 183-187.

Carls, P. 1986. Neue Arten von Vandercammenina und Hysterolites (Brachiopoda, Acrospiriferinae; Devon). Senckenbergiana lethaea, 67, 33-41.

Carls, P. 1988. The Devonian of Celtiberia (Spain) and Devonian paleogeography of SW Europe. In: Devonian of the World. Proceedings $2^{\text {nd }}$ International Symposium on the Devonian System, Calgary, 1987, (eds McMillan, N.J., Embry, A.F. \& Glass, D.J.). Canadian Society of Petroleum Geologists Memoir, 14, 421-466.

Carls, P. 1999. El Devónico de Celtiberia y sus fósiles. In: Veinticinco Años de Paleontología Aragonesa, Homenaje al Profesor L. Sequeiros, (ed. Gámez-Vintaned, J.A.). VI Jornadas Aragonesas de Paleontología, Institución Fernando El Católico, Diputación de Zaragoza, 101-164.

Carls, P. \& Valenzuela-Ríos, J.I. 1999. Similitudes y diferencias estratigráficas entre el Pridoliense-Praguiense celtibérico y armoricano. Revista Española de Paleontología, 14, 279-292.

Carls, P., Meyn, H. \& Vespermann, J. 1993. Lebensraum, Entstehung und Nachsfahren von Howellella (Iberohowellella) hollmanni n. sg., n. sp. (Spiriferacea, Lochkovium, Unter-Devon). Senckenbergiana lethaea, 73, 227-267.

Cooper, G.A. 1956. Chazian and related brachiopods. Smithsonian Miscellaneous Collections, 127, 1-1245.

Dojen, C. 2005. Early Devonian Ostracods from Celtiberia (NE Spain) - taxonomy, palaeoecology, biostratigraphy, and biogeography. Fakultät für Physik und Geowissenschaften der Technischen Universität Carolo-Wilhelmina zu Braunschweig, Dissertations, $256 \mathrm{pp}$.

Drot, J. \& L'Hotellier, J. 1976. Les Brachiopodes Rhynchonellida. In: Les Schistes et Calcaires Eodévoniens de Saint Cénéré (Massif Armloricain, France). Sédimentologie, Paléontologie, Stratigraphie, (coordinateur Lardeux, H.). Mémoires de la Société Géologique et Minéralogique de Bretagne, 19, 263-271.

García-Alcalde, J.L. 1996. El Devónico del Dominio AsturLeonés en la Zona Cantábrica ( $\mathrm{N}$ de España). Revista Española de Paleontología, No Extra, 58-71.

García-Alcalde, J.L. 1998. Braquiópodos rinconélidos del Lochkoviense (Devónico Inferior) de la Cordillera Cantábrica (Norte de España). Géobios, 31, 767-789; doi: 10.1016/S0016-6995(98)80108-3.

García-Alcalde, J.L. 2009. Iberirhynchiidae nueva familia de rinconélidos Ancystrorhynchoideos (braquiópodos) del Ordovícico Medio al Devónico Inferior de Euroamérica y Gondwana. Revista Española de Paleontología, 24, 149-169.

García-Alcalde, J.L. 2013. Terebratúlidos (braquiópodos) del Devónico de la Cordillera Cantábrica ( $\mathrm{N}$ de España). Trabajos de Geología, 33, 17-170.

García-Alcalde, J.L. 2014. Beethovenia n. gen. y Plicostropheodonta Sokolskaya, 1960 (Strophodontidae
Caster, 1939), del Devónico Inferior de Europa occidental. Trabajos de Geología, 34, 19-60.

García-Alcalde, J.L. \& Herrera, Z. 2015. Braquiópodos del Devónico Inferior (Lochkoviense-Praguiense) de la región Cántabro-Celtibérica (España). Trabajos de Geología, 35, 99-138.

García-Alcalde, J.L., Arbizu, M., García-López, S., Leyva, F., Montesinos, R., Soto, F. \& Truyols-Massoni, M. 1990. Devonian stage boundaries (Lochkovian/Pragian, Pragian/ Emsian, and Eifelian/Givetian) in the Cantabric region (NW Spain). Neues Jahrbuch Geologie und Paläontologie Abhandlungen, 180, 177-207.

García-López, S. \& Sanz-López, J. with contributions by G.N. Sarmiento. 2002. The Palaeozoic succession and conodont biostratigraphy of the section between Cape Peñas and Cape Torres (Cantabrian coast, NW Spain). Cuadernos del Museo Geominero, 1, 125-161.

García-López, S. \& Sanz-López, J. 2002. Devonian to Lower Carboniferous conodont biostratigraphy of the Bernesga Valley section (Cantabrian Zone, NW Spain). Cuadernos del Museo Geominero, 1, 163-205.

Havlíček, V. 1959. Rhynchonellacea im böhmischen älteren Paläozoicum (Brachiopoda). Věstník Ústředního ústavu geologického, 34, 78-82.

Havlíček, V. 1982. New genera of thynchonellid and camerellid brachiopods in the Silurian of Bohemia. Věstnik Ústředního ústavu geologického, 57, 365-372.

Havlíček, V. \& Storch, P. 1990. Silurian brachiopods and benthic communities in the Prague Basin (Czechoslovakia). Rozpravy Ústředního ústavu geologickeho, 48, 1-275.

Oehlert, D. 1884. Étude sur quelques brachiopodes dévoniens. Bulletin de la Société Géologique de France, 12, 411-441.

Orbigny, A. d' 1850. Prodrome de Paléontologie Stratigraphique Universelle. Vol. I. 392 pp. Victor Masson, Paris.

Racheboeuf, P.R. 1981. Chonetacés (Brachiopodes) Siluriens et Dévoniens du Sud-Ouest de l'Europe. Mémoires de la Société Géologique et Minéralogique de Bretagne, 27, 1-294.

Rouault, M. 1846. Catalogue des fossils du terrain paléozoique des environs de Rennes. Bulletin de la Société géologique de France, 2, 320-328, 13: 295-353.

Savage, N.M. 2002. Rhynchotrematoidea. In: Treatise on Invertebrate Paleontology, Part H, Brachiopoda, Revised, Volume 4, Rhynchonelliformea (Part), (ed. Kaesler, R.L.). The Geological Society of America and The University of Kansas, Boulder, Colorado, and Lawrence, 1047-1091.

Savage, N., Manceñido, M.O., Owen, E.F., Carlson, S.J., Grant, R.E., Dagys, A.S. \& Sun, D.-L. 2002. Rhynchonellida. In: Treatise on Invertebrate Paleontology. Part H, Brachiopoda Revised, Volume 4: Rhynchonelliformea (Part), (ed. Kaesler, R.L.). The Geological Society of America, Inc. \& The University of Kansas, Boulder, Colorado, and Lawrence, Kansas, 1027-1376.

Schemm-Gregory, M. 2011. A new species of Neopaulinella (Brachiopoda, Terebratulida) from the Eastern Iberian Chains, Spain (Lower Devonian). Bulletin of Geosciences, 86, 227-240; doi: 10.3140/bull.geosci.1244. 
Sommer, W. 1965. Stratigraphic und Tektonik im östlichen Guadarrama-Gebirge (Spanien). Arbeiten aus dem Geologisch-Paläontologischen Institut Westf., WilhemsUniversität zu Münster, 1, 1-159.

Williams, A. \& Brunton, C.H.C. 1997. Morphological and anatomical terms applied to brachiopods. With contributions from other contributors to this revision of Part H. In: Treatise on Invertebrate Paleontology, Part H Brachiopoda Revised, Volume 1: Introduction, (ed. Kaesler, R.L.). The Geological Society of America, Inc. \& The University of Kansas, Boulder, Colorado, and Lawrence, Kansas, 423-440. 